\title{
The effect of circadian rhytm in patients undergoing spinal anesthesia
}

\author{
Spinal anestezi uygulanan hastalarda sirkadiyen ritmin etkisi
}

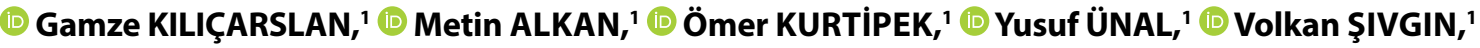 \\ (D) Kürşat DIKMEN, ${ }^{2}$ (D) Semin TURHAN, ${ }^{1}$ (D) Mustafa ARSLAN'
}

\begin{abstract}
Summary
Objectives: The circadian rhythm is the most important of the main rhythms that affect our daily lives and has a significant role in the efficiency of a lot of drugs used in anesthesia. The aim of this study is to prove whether circadian rhythm has an effect on spinal anesthesia and, if any, its effect on post-operative analgesic request by retrospectively studying the patients operated under spinal anesthesia.
\end{abstract}

Methods: We conducted the study on patients operated on inguinal hernia and anorectal surgery under spinal anesthesia in general surgery room. The patients were divided into two groups according to the time when they were taken into surgery: Between 06.00-12.00 (Group 1) and 12.00-18.00 (Group 2). Time to first analgesic request, time to start walking, time to first urination, intraoperative and post-operative side effects, intraoperative hemodynamic data, and patient satisfaction were detected and recorded.

Results: The time to first analgesic request in Group 1 was longer than in Group 2, and this difference was statistically significant. The mean heart rate of the groups was found significantly lower in Group 2 than in Group 1 during measurements at the 25 and 30 min when compared with their changes overtime. There were no statistically significant differences between the groups in terms of side effects and the most common side effect was detected to be nausea-vomiting.

Conclusion: We found out that the time to first analgesic request after spinal anesthesia was significantly longer in Group 1 than in Group 2.

Keywords: Circadian rhythm; post-operative analgesia; spinal anesthesia.

\section{Öz}

Amaç: Sirkadiyen ritim günlük yaşamımızda etkisi altında kaldığımız başlıca ritimlerden en önemlisidir ve anestezide kullandığımız birçok ilacın etkinliğinde önemli rol oynamaktadır Bu çalışmanın amacı spinal anestezi altında opere olan hastaları retrospektif olarak inceleyerek sirkadiyen ritmin spinal anestezi uygulanan hastalarda postoperatif analjezi gereksinimi üzerine olan etkisini ortaya koymaktır.

Gereç ve Yöntem: Çalışmamız spinal anestezi altında genel cerrahi ameliyathanesinde ingüinal herni ve anorektal cerrahi operasyonu geçiren hastalarda gerçekleştirildi. Hastalar cerrahiye alındıkları saate göre iki gruba ayrıldı: Saat 06.00-12.00 (Grup 1) ve 12.00-18.00 (Grup 2). Postoperatif ilk analjezik gereksinim süreleri, ilk yürüme zamanları, ilk idrar yapma zamanları, intraoperatif hemodinamik veriler, intraoperatif ve postoperatif yan etkiler ve hasta memnuniyetleri belirlenerek kaydedildi.

Bulgular: Postoperatif ilk analjezik ihtiyacı zamanı Grup 1'de Grup 2'ye göre daha uzun saptanmış olup, bu fark istatistiksel olarak anlamlı bulundu. Gruplara ait kalp atım hızı ortalamaları, zaman içerisindeki değişimleri açısından karşılaştırıldığında 25. ve 30. dakika ölçümlerinde Grup 2'de Grup 1'e göre anlamlı olarak düşük bulundu. Yan etkilere bakıldığında gruplar arası istatistiksel olarak anlamlı bir fark olmadığı, iki grupta da en sık görülen yan etkinin bulantı-kusma olduğu tespit edildi.

Sonuç: Spinal anestezi sonrası ilk analjezi gereksinim zamanının Grup 1'de Grup 2'ye göre anlamlı derecede uzun olduğunu saptadık.

Anahtar sözcükler: Sirkadiyen ritim; postoperatif analjezi; spinal anestezi.

\footnotetext{
'Department of Anesthesiology and Reanimation, Gazi University, Medical Faculty, Ankara, Turkey

${ }^{2}$ Department of General Surgery, Gazi University, Medical Faculty, Ankara, Turkey
}

Submitted (Başvuru tarihi) 22.05.2020 Accepted after revision (Düzeltme sonrası kabul tarihi) 10.01.2021 Available online date (Online yayımlanma tarihi) 06.07.2021

Correspondence: Dr. Metin Alkan. Gazi Üniversitesi Tıp Fakültesi, Anesteziyoloji ve Reanimasyon Anabilim Dalı, Ankara, Turkey.

Phone: +90 - 312 - 2024166 e-mail: metoalkan@gmail.com

(c) 2021 Turkish Society of Algology 


\section{Introduction}

There are several rhythms that affect us in our daily lives and the most important of them is the circadian rhythm regulated by the suprachiasmatic nucleus in the anterior hypothalamus. ${ }^{[1]}$

Circadian rhythm shows changes in the physiological and biological process of the organism for about 1 day. The sleep-wake cycle in human is the most basic and determining circadian rhythm. ${ }^{[2-5]}$ Circadian rhythm is of great significance in terms of taking drugs at the right time. The correct intake of drugs is important in terms of pharmaco/toxicodynamics and pharmaco/toxicokinetics of the drug. Due to the circadian rhythm, taking drugs at the right time are important in terms of providing minimum toxicity and maximum efficacy of them.

Biological rhythms have been observed to change the pharmacology and effects of anesthetic agents such as local anesthetic, hypnotic, analgesic, and muscle relaxants. ${ }^{[6-9]}$ However, there are a limited number of studies on regional anesthesia and local anesthetics utilized for this purpose and these studies are often about labor analgesia although there are animal and human studies on the agents used in general anesthesia. In our literature review, we did not find any publishing on the circadian effect of spinal anesthesia given to this group of patients. Thus, in this study, we researched on the effect of circadian rhythm on analgesic request in patients who were administered spinal anesthesia, by comparing two different times during the day. We have also examined whether circadian rhythm has any effects on the found out side effects during the post-operative follow-up of the patients taken at two different times.

\section{Material and Methods}

This study was carried out in the Department of Anesthesiology and Reanimation of Gazi University Faculty of Medicine after getting the approval of the Faculty Ethics Committee (April 30, 2018-330) by retrospectively scanning files of 18-65-year-old patients with American Society of Anesthesiologists (ASA) I-II-III, between January 1, 2016, and January 1, 2018, who operated on for inguinal hernia and anorectal surgery (perianal fistula, hemorrhoid, and anal fissure) under spinal anesthesia in the general surgery room and also by obtaining patient data from file records and post-operative analgesia follow-up forms. Patients given hyperbaric bupivacaine (Bupivacaine Spinal Heavy $0.5 \%$, On Pharma, Turkey) of $3 \mathrm{ml}(15 \mathrm{mg}$ ) were included in the study. Patients who had been administered any kind of anesthesia other than spinal anesthesia, having inadequate file records and inadequate post-operative analgesia follow-up records were excluded from the study.

Patients were divided into two groups according to the time when they were taken to surgery: Between 06.00-12.00 (Group 1) and 12.00-18.00 (Group 2) and recorded in follow-up forms in view of the data obtained from the file records.

The files of the patients were examined and their demographic data such as age (year), body weight (kg), height (cm), gender, ASA scores (I-III), time to perform spinal anesthesia, and duration of anesthesia and surgery were all recorded. Patients' additional diseases such as hypertension, diabetes mellitus, coronary artery disease, and chronic obstructive pulmonary disease were questioned. Intraoperative systolic arterial pressure (SAP), diastolic arterial pressure (DAP), mean arterial pressure (MAP), and heart rate (HR) were recorded before the operation (control) and at the 5, 10, $15,20,25$, and 30 minute ( $\mathrm{min}$ ), and at the end of the process (end). Side effects in the perioperative period such as nausea-vomiting, hypotension, bradycardia, urinary retention, tremors, pruritus, headache, dizziness, and temporary neurological symptoms, spinal range interference level (L2-3, L3-4, L4-5), time to reach adequate anesthesia level ( $\mathrm{T} 10)$ for surgery, and types of operations (inguinal hernia and anorectal surgery) were obtained and recorded from the files. In the post-operative period, time to first analgesic request (min), time to start walking ( $\mathrm{min}$ ), time to first urination ( $\mathrm{min}$ ), and presence of urinary catheters, if any, were determined and recorded in patient follow-up forms. Patients operated on for anorectal surgery and inguinal hernia under spinal anesthesia in our general surgery clinic are intravenously given tramadol $1 \mathrm{mg} /$ $\mathrm{kg}$ (Tradolex $100 \mathrm{mg} / 2 \mathrm{~mL}$, Menta, Turkey) and tenoksikam 20 mg (Tilcotil 20 mg/2 mL, Deva Holding, Turkey), if needed, after they start to have pain.

In the post-operative period, patient satisfaction was evaluated and recorded by means of a 5-point scale $(0=$ bad, $1=$ moderate, $2=$ good, $3=$ very good, and $4=$ excellent). 
Table 1. Demographic characteristics of patients in groups

\begin{tabular}{|c|c|c|c|}
\hline & Group $1(n=185)$ & Group $2(n=107)$ & $\mathbf{p}$ \\
\hline Age (year), Mean $\pm S D$ & $48.97 \pm 15.39$ & $45.58 \pm 17.02$ & 0.083 \\
\hline Body weight $(\mathrm{kg})$, Mean \pm SD & $78.48 \pm 13.29$ & $76.54 \pm 13.07$ & 0.246 \\
\hline Height $(\mathrm{cm})$, Mean \pm SD & $171.05 \pm 7.74$ & $172.44 \pm 7.87$ & 0.170 \\
\hline Gender (F/M), Mean \pm SD & $42 / 143$ & $22 / 85$ & $\begin{array}{l}x^{2}=0.431 \\
p=0.511\end{array}$ \\
\hline ASA (I/II/III) & $93 / 69 / 5$ & $57 / 43 / 2$ & \\
\hline \multicolumn{4}{|l|}{ Additional disease (n) } \\
\hline $\mathrm{HT}$ & 32 & 15 & $\begin{array}{l}x^{2}=0.879 \\
p=0.348\end{array}$ \\
\hline DM & 11 & 5 & $\begin{array}{l}x^{2}=0.325 \\
p=0.569\end{array}$ \\
\hline CAD & 11 & 5 & $\begin{array}{l}x^{2}=0.325 \\
p=0.569\end{array}$ \\
\hline COPD & 5 & 6 & $\begin{array}{l}x^{2}=1.339 \\
p=0.247\end{array}$ \\
\hline
\end{tabular}

SD: Standard deviation; F: Female; M: Male; ASA: American Society of Anesthesiologists; HT: Hypertension; DM: Diabetes mellitus; CAD: Coronary artery disease; COPD: Chronic obstructive pulmonary disease.

\section{Statistical analysis}

Statistical analyses were performed by SPSS statistical package for Windows (Chicago, Illinois). Parametric values were evaluated with the Student's t-test. Repeated measurements (HR and SAP/DAP/MAP) were analyzed using repeated measures analysis of variance. Side effects, gender, and ASA status were compared using $X^{2}$ and Fisher's exact tests. $p<0.05$ was considered statistically significant.

\section{Results}

This study involved a total of 292 patients in ASA IIII group. There was no statistically significant difference in the demographic characteristics of the patient groups involved in our study. The incidence of additional diseases in patients included in our study was similar between the groups (Table 1).

When their operation times were compared between the groups, it was found out that there was no significant difference and the mean duration of operation was similar in both groups. When the time to sensory block required for surgical intervention was compared, no statistical difference was detected between the groups. There were no significant differences when the types of operations were evaluated between the groups. Mostly, inguinal hernia opera- tion was performed in both groups. The intervention sites, mostly in the L3-4 regions, were found to be similar in both groups (Table 2).

When HR averages of the groups were compared with regard to their changes overtime, it was found out that they were significantly lower in Group 2 than in Group 1 in terms of 25 and 30 min measurements ( $p=0.034$ and $p=0.039$, respectively) (Table 3 ). When the differences between groups overtime were compared to the control value, it was seen that the mean values of HR in both groups were not statistically different from the mean control HR (Table 3).

Mean values of SAP, DAP, and MAP according to the measurement times are shown in Table 4. When SAP, DAP, and MAP averages of the groups were compared in terms of changes overtime, there was no difference between the groups. When the within-group differences overtime were studied, the mean values of SAP, DAP, and MAP in both groups were statistically different from the mean control SAP, DAP, and MAP at other measurement times except for that of 5 min measurement $(p<0.05)$ (Table 4).

Side effects determined in the perioperative period are shown in Table 5. There was no statistically significant difference regarding the detected side effects 
Table 2. Duration of surgery, time to reach adequate anesthesia level for surgery, spinal range interference level, and types of operations

\begin{tabular}{|c|c|c|c|}
\hline & $\begin{array}{l}\text { Group } 1 \\
(n=185)\end{array}$ & $\begin{array}{l}\text { Group } 2 \\
(n=107)\end{array}$ & $\mathbf{p}$ \\
\hline Duration of surgery (min), Mean \pm SD & $40.17 \pm 22.18$ & $42.82 \pm 21.50$ & 0.714 \\
\hline Time to reach adequate anesthesia level for surgery $(\mathrm{min})(\mathrm{T} 10)$, Mean $\pm \mathrm{SD}$ & $4.40 \pm 1.82$ & $4.83 \pm 2.19$ & 0.172 \\
\hline Spinal range interference level (L2-3, L3-4, and L4-5), n & $4 / 161 / 21$ & $4 / 91 / 11$ & $\begin{array}{l}x^{2}=0.705 \\
p=0.703\end{array}$ \\
\hline Types of operations (inguinal hernia/anorectal surgery), $n$ & $101 / 84$ & $55 / 51$ & $\begin{array}{l}x^{2}=1.339 \\
p=0.247\end{array}$ \\
\hline
\end{tabular}

SD: Standard deviation.

Table 3. Heart rate per each group

\begin{tabular}{lccc}
\hline Time & $\begin{array}{c}\text { Group 1 } \\
(\mathbf{n = 1 8 5})\end{array}$ & $\begin{array}{c}\text { Group 2 } \\
(\mathbf{n = 1 0 7 )}\end{array}$ & $\mathbf{p}$ \\
\hline Control & $85.39 \pm 16.04$ & $86.63 \pm 18.11$ & 0.397 \\
$5 \mathrm{~min}$ & $81.85 \pm 14.92$ & $81.24 \pm 16.66$ & 0.753 \\
$10 \mathrm{~min}$ & $81.87 \pm 15.54$ & $78.02 \pm 16.23$ & 0.052 \\
$15 \mathrm{~min}$ & $78.23 \pm 14.93$ & $75.55 \pm 14.80$ & 0.161 \\
$20 \mathrm{~min}$ & $75.80 \pm 14.30$ & $73.71 \pm 14.86$ & 0.273 \\
$25 \mathrm{~min}$ & $75.75 \pm 13.06$ & $71.54 \pm 14.65$ & 0.034 \\
$30 \mathrm{~min}$ & $75.14 \pm 12.21$ & $71.01 \pm 14.22$ & 0.039 \\
End of the process & $75.17 \pm 12.79$ & $72.34 \pm 13.55$ & 0.081 \\
\hline
\end{tabular}

Values: Beat/min; mean \pm SD. SD: Standard deviation.

between the groups. The most common side effect was nausea-vomiting in both groups (Table 5).

The time to first analgesic request in post-operative period was longer in Group 1 when compared to Group 2, and this difference was found to be statistically significant $(p<0.0001)$ (Table 6).

Time to first mobilization, time to first urination, number of patients with a urinary catheter, and patient satisfaction were found to be similar between the groups (Table 6).

\section{Discussion}

Although there are a great number of studies as to the efficacy and toxicity of circadian rhythm on general anesthetic agents, there are a limited number of studies about its efficacy on regional anesthesia. Animal studies have shown that the maximum hypnotic effect of general anesthetics is generally provided during the resting period corresponding to night for humans. ${ }^{[10,11]}$ Similarly, it is known that pain-related mediators show variations throughout the day. ${ }^{[12]}$ Aya et al. ${ }^{[13]}$ showed the presence of circadian change in the perception of birth pain and stated that the visual analog scale (VAS) scores were lower in morning-afternoon group than evening-night group. A peak activity of morphine and tramadol has been detected in mice during the activity period. ${ }^{[14,15]}$ In the case of human studies, Auvil-Novak et al. ${ }^{[16]}$ observed that the highest and lowest demands of morphine or hydromorphone, respectively, occurred early in the morning and during the night. Boom et al. ${ }^{[17]}$ observed that the peak of pain relief occurred at 17:30 and it was the lowest early in the morning $(05: 30)$. Whereas, the need for fentanyl in the post-operative period was compared at two different times in a group of patients administered elective cholecystectomy. The need for fentanyl was lower in patients who were operated earlier in the morning (08:00-10:00) compared to those that were operated at later hours (11:00-15:00). ${ }^{[18]}$ We think that there is a correlation between the fact that the need for fentanyl was low in the morning and the fact that time to first analgesic request was longer in the patients who were in the morning group for our study.

Very little is known referring to the chronopharmacokinetic variability of opioids that are used in the course of general anesthesia. There were no circadian changes in fentanyl clearance in six volunteers who had $50 \mu \mathrm{g} / \mathrm{h}$ fentanyl infusion for $48 \mathrm{~h} \cdot{ }^{[19]}$ However, Pan et al. ${ }^{[20]}$ reported that the period of analgesia of subarachnoid fentanyl utilized in labor analgesia was shorter during the night than in the afternoon. Debon et al. ${ }^{[21]}$ observed a variation in the duration of analgesia at acrophase with subarachnoid sufentanil, which varied $30 \%$. Chronopharmacological 
Table 4. SAP, DAP, and MAP ( $\mathrm{mmHg}$ ) per each group

\begin{tabular}{|c|c|c|c|}
\hline Time & $\begin{array}{c}\text { Group } 1 \\
(n=185) \\
\text { Mean } \pm \text { SD }\end{array}$ & $\begin{array}{c}\text { Group 2 } \\
(n=107) \\
\text { Mean } \pm \text { SD }\end{array}$ & $\mathbf{p}$ \\
\hline \multicolumn{4}{|l|}{ Control } \\
\hline SAP & $146.38 \pm 21.57$ & $143.39 \pm 21.25$ & 0.258 \\
\hline DAP & $84.67 \pm 13.49$ & $82.43 \pm 13.53$ & 0.180 \\
\hline MAP & $107.51 \pm 16.89$ & $104.81 \pm 16.67$ & 0.197 \\
\hline \multicolumn{4}{|l|}{$5^{\text {th }} \min$} \\
\hline SAP & $132.77 \pm 21.87$ & $131.50 \pm 18.84$ & 0.621 \\
\hline DAP & $76.81 \pm 14.03$ & $74.03 \pm 12.99$ & 0.100 \\
\hline MAP & $97.00 \pm 17.26$ & $95.56 \pm 14.78$ & 0.478 \\
\hline \multicolumn{4}{|l|}{$10^{\text {th }} \min$} \\
\hline SAP & $126.78 \pm 20.33^{*}$ & $123.54 \pm 19.43^{*}$ & 0.191 \\
\hline DAP & $73.99 \pm 12.65^{*}$ & $71.26 \pm 12.21^{*}$ & 0.078 \\
\hline MAP & $93.55 \pm 14.25^{*}$ & $91.38 \pm 13.63^{*}$ & 0.211 \\
\hline \multicolumn{4}{|l|}{$15^{\text {th }} \min$} \\
\hline SAP & $122.00 \pm 17.92^{*}$ & $122.18 \pm 18.42^{*}$ & 0.937 \\
\hline DAP & $71.56 \pm 11.45^{*}$ & $70.52 \pm 12.17^{*}$ & 0.488 \\
\hline MAP & $89.83 \pm 13.46^{*}$ & $89.93 \pm 13.80^{*}$ & 0.955 \\
\hline \multicolumn{4}{|l|}{$20^{\text {th }} \min$} \\
\hline SAP & $119.64 \pm 16.65^{*}$ & $122.00 \pm 17.43^{*}$ & 0.291 \\
\hline DAP & $70.63 \pm 11.59^{*}$ & $69.62 \pm 11.82^{*}$ & 0.511 \\
\hline MAP & $88.60 \pm 12.72^{*}$ & $90.09 \pm 13.40^{*}$ & 0.381 \\
\hline \multicolumn{4}{|l|}{$25^{\text {th }} \min$} \\
\hline SAP & $120.09 \pm 17.77^{*}$ & $120.01 \pm 17.62^{*}$ & 0.974 \\
\hline DAP & $70.14 \pm 10.79 *$ & $68.55 \pm 11.40^{*}$ & 0.308 \\
\hline MAP & $88.74 \pm 12.15^{*}$ & $88.48 \pm 13.22^{*}$ & 0.882 \\
\hline \multicolumn{4}{|l|}{$30^{\text {th }} \min$} \\
\hline SAP & $119.66 \pm 15.43^{*}$ & $118.81 \pm 16.51^{*}$ & 0.714 \\
\hline DAP & $70.49 \pm 10.00^{*}$ & $67.95 \pm 11.54^{*}$ & 0.105 \\
\hline MAP & $88.95 \pm 11.08^{*}$ & $88.14 \pm 12.69^{*}$ & 0.641 \\
\hline \multicolumn{4}{|c|}{$\begin{array}{l}\text { End of } \\
\text { the process }\end{array}$} \\
\hline SAP & $121.17 \pm 17.11^{*}$ & $120.74 \pm 14.89 *$ & 0.830 \\
\hline DAP & $70.93 \pm 10.87^{*}$ & $68.31 \pm 10.96^{*}$ & 0.053 \\
\hline MAP & $89.18 \pm 12.01^{*}$ & $88.57 \pm 11.96^{*}$ & 0.684 \\
\hline
\end{tabular}

*: $\mathrm{P}<0.05$ (compared within-control value); SD: Standard deviation; SAP: Systolic arterial pressure; DAP: Diastolic arterial pressure; MAP: Mean arterial pressure.

studies regarding nonsteroidal anti-inflammatory drugs have indicated that, when given at 07:00, indomethacin and ketoprofen reached higher plasma levels compared to day or night hours. ${ }^{[22,23]}$

Significant differences have been shown in the various application areas in terms of duration of action
Table 5. Perioperative side effects

\begin{tabular}{|c|c|c|c|c|c|}
\hline \multirow[t]{2}{*}{ Time } & \multicolumn{2}{|c|}{$\begin{array}{l}\text { Group } 1 \\
(n=185)\end{array}$} & \multicolumn{2}{|c|}{$\begin{array}{l}\text { Group } 2 \\
(n=107)\end{array}$} & \multirow[t]{2}{*}{$\mathbf{p}$} \\
\hline & $\mathbf{n}$ & $\%$ & $\mathbf{n}$ & $\%$ & \\
\hline Nausea and vomiting & 15 & 9.3 & 8 & 9.3 & - \\
\hline Hypotension & 13 & 8.1 & 7 & 8.1 & - \\
\hline Bradycardia & 3 & 1.9 & 3 & 3.5 & $\begin{array}{l}x^{2}=0.625 \\
p=0.429\end{array}$ \\
\hline Shivering & 2 & 1.2 & 0 & 0 & $\begin{array}{l}x^{2}=1.721 \\
p=0.544\end{array}$ \\
\hline Itching & 1 & 0.6 & 1 & 1.2 & $\begin{array}{l}x^{2}=0.195 \\
p=0.659\end{array}$ \\
\hline Headache & 1 & 0.6 & 3 & 3.5 & $\begin{array}{l}x^{2}=2.735 \\
p=0.098\end{array}$ \\
\hline Dizziness & 8 & 5.0 & 5 & 5.8 & $\begin{array}{l}x^{2}=0.079 \\
p=0.778\end{array}$ \\
\hline Urine retention & 13 & 8.1 & 5 & 5.8 & $\begin{array}{l}x^{2}=0.424 \\
p=0.515\end{array}$ \\
\hline TNS & 0 & 0.0 & 0 & 0.0 & - \\
\hline
\end{tabular}

TNS: Temporary neurological symptoms.

of local anesthetics according to the administration time. ${ }^{[6,24]}$ In a study in which the duration of ropivacaine was tested for the presence of a circadian rhythm when injected epidurally at birth, significant differences were shown according to the administration time in terms of the duration of analgesia of ropivacaine given at the same dose, and the duration of analgesia was found to be $20-28 \%$ longer during the day period. ${ }^{[8]}$ Similarly, the circadian rhythm of the duration of local anesthesia for lidocaine, betoxycaine, mepivacaine, and articaine was shown in the course of dental surgery. The amide derivative used showed similar findings for all these agents, regardless of the kind of local anesthetics, and it was reported that their longest activity was occurred when applied at about 3 pm in the afternoon. ${ }^{[24]}$

In our study, we found that time to first analgesic request in the morning group (Group 1) was significantly longer than in Group 2 in the afternoon period. Our results do not appear to be consistent with the longest duration of anesthesia observed at 15:00 in the previous studies which show the circadian rhythm of the duration of local anesthesia induced by both dental procedures and lidocaine in skin ${ }^{[6]}$ In addition, the duration of action of ropivacaine which is used epi- 
Table 6. Duration of analgesia, time to first mobilization and urination, patients with urinary catheter, and anesthesia satisfaction level

\begin{tabular}{lccc}
\hline & $\begin{array}{c}\text { Group 1 } \\
\text { (n=185) }\end{array}$ & $\begin{array}{c}\text { Group 2 } \\
\text { (n=107) }\end{array}$ & p \\
\hline The time to first analgesic request (min), Mean \pm SD & $328.04 \pm 184.70$ & $226.90 \pm 130.46^{*}$ & $<0.0001$ \\
Time to first mobilization (min), Mean \pm SD & $462.16 \pm 130.69$ & $452.87 \pm 139.85$ & 0.609 \\
Time to first urination (min), Mean \pm SD & $445.03 \pm 119.41$ & $430.78 \pm 103.80$ & 0.413 \\
Patients with urinary catheter, $\mathrm{n}$ & 15 & 5 & $X^{2}=0.857$ \\
Patient satisfaction (0-4), Mean \pm SD & & $3.22 \pm 0.83$ & 0.354 \\
\hline
\end{tabular}

SD: Standard deviation; *: $p<0.05$ (compared with Group 1).

durally in the delivery analgesia for pregnant patients was found to be longer in the daytime period comparing to the night period ${ }^{[8]}$ However, these studies were formed by local anesthetic injections given 4 or 6 times a day followed by the duration of analgesia. In our study, we compared the time periods just in the morning and afternoon, and we are of the opinion that there is a need for comparisons including night period. In addition, many mechanisms have been stated to play a role here. First, it has been reported that the membrane nerve cell permeability shows circadian rhythm. ${ }^{[25]}$ Similarly, the $\mathrm{K}^{+}$efflux from cells is lowest around 15:00; ${ }^{[26]}$ catecholamine release has a possible effect ${ }^{[27]}$ and the hormonal mechanisms such as progesterone play a role. ${ }^{[28]}$ In humans, cortisol levels increase throughout the night and reach the highest level around 07-08 in the morning, and therefore, in stressful situations over waking up play an important role in endocrine balance. ${ }^{[29]}$ It is also known that acetylcholine levels are the highest during the day which is the active phase. ${ }^{[30]}$ Studies have shown that antinociceptive hormones show diurnal variation and are present in higher plasma concentrations during the morning hours. ${ }^{[31,32]}$ These hormones are likely to play an important role in the perception of pain. It is clear that the utilized method of anesthesia can also be effective in diurnal variation. Therefore, as shown in our study, we think that all these factors may be effective in that time to first analgesic request is longer in the morning group. Although, in the previous studies, it was reported that gender was effective, in this study, we had patients of both sexes and female/male ratio was not different between the groups.

Significant changes in the stability of the circulation are known to be associated with the sensorial level of spinal anesthesia. Arterial blood pressure displays known a circadian rhythm pattern that reaches the peak early in the morning and the lowest at night. ${ }^{[33]}$ In our study, no difference was detected between the groups in SAP, DAP, and MAP values. Nevertheless, a significant decrease was found in all measurement values after the $5^{\text {th }}$ min according to SAP, DAP, and MAP within-group control values. In fact, it was an expected situation. Because the decrease of the values after the $5^{\text {th }}$ min is a situation that we expect in spinal anesthesia depending on the time and level of sympathetic block. On the one hand, we could not find a significant difference between the patients before and after noon.

On the other hand, though there were not any differences in HRs according to the within-group control values, we detected a significant difference between the groups at the $25^{\text {th }}$ and $30^{\text {th }} \mathrm{min}$. We found that the HRs at $25^{\text {th }}$ and $30^{\text {th }}$ min were significantly higher in Group 1 patients taken before noon than Group 2. We did not record the values after the $30^{\text {th }} \mathrm{min}$. However, the HRs after the $25^{\text {th }}$ min were likely to increase at significant levels in Group 1 comparing to Group 2. We think that this may be due to the high diurnal rhythm of cortisol for the morning hours. However significant, it may seem in statistical terms, yet we think that this situation is of no clinical meaning.

There was no significant difference in the time to first mobilization between the groups, which is another finding in our study. This may probably be associated to time to mobilization routinely ordered to patients.

Several studies have shown time-dependent differences in the toxicity, pharmacokinetics, and pharmacodynamics of local anesthetics. The highest toxicity 
for amide type agents in rodents has been observed either at the beginning of the activity or at the end of the rest phase. ${ }^{[34]}$

In combined spinoepidural technique for labor analgesia, in patients given ropivacaine + fentanyl, there were not any differences in day and night groups in terms of complications. ${ }^{[35]}$ Furthermore, in our study, we could not detect any difference in perioperative complications between the groups before noon and afternoon. Whereas, we found that the most common side effect was nausea and vomiting. This finding appears to be in line with the high incidence of nausea and vomiting in the literature. ${ }^{[36]}$

Although the duration of analgesia showed diurnal variation in the previous studies, no difference was found in terms of VAS values. ${ }^{[8]}$ Since our study was a retrospective one, we could not determine the VAS values. However, we were able to measure patient satisfaction. In this study, we could not detect any differences between the groups in terms of patient satisfaction. This may have possibly resulted from a routine analgesic protocol followed for all patients in the post-operative period. Because patients were provided with routine analgesic medication at certain intervals after their first analgesic request.

\section{Limitations}

We regarded as a deficiency that we planned our study retrospectively. We think that prospective studies evaluating VAS values and analgesic consumption on this matter. Another deficiency of our study is that we could not evaluate $24 \mathrm{~h}$ period including the nighttime since these patients are taken into operation only during the day period in our clinic.

\section{Conclusion}

As a result, we found that time to first analgesic request was longer in the morning group given spinal anesthesia than in the afternoon group. Nevertheless, we think that prospective studies ought to be performed including a comparison of day and night time. In this context, we think that the dosage of the drugs can be rearranged in the near future according to the administration hours to maximize the efficacy of the anesthetic agents we use in our daily practice and to reduce the undesirable side effect rates and that new studies aiming at this subject are required.
Conflict-of-interest issues regarding the authorship or article: None declared.

\section{Peer-rewiew: Externally peer-reviewed.}

\section{References}

1. Lee HS, Billings HJ, Lehman MN. The suprachiasmatic nucleus: A clock of multiple components. J Biol Rhythms 2003;18(6):435-49. [CrossRef]

2. Zee PC, Manthena P. The brain's master circadian clock: İmplications and opportunities for therapy of sleep disorders. Sleep Med Rev 2007;11(1):59-70. [CrossRef]

3. Okamura H. Integration of mammalian circadian clock signals: From molecule to behavior. J Endocrinol 2003;177(1):3-6. [CrossRef ]

4. Gery S, Komatsu N, Baldjyan L, Yu A, Koo D, Koeffler HP. The circadian gene per1 plays an important role in cell growth and DNA damage control in human cancer cells. Mol Cell 2006;22(3):375-82. [CrossRef ]

5. Arendt J. Melatonin and human rhythms. Chronob Int 2006;23(1-2):21-37. [CrossRef ]

6. Reinberg A, Reinberg MA. Circadian changes of the duration of action of local anaesthetic agents. Naunyn Schmiedebergs Arch Pharmacol 1977;297(2):149-52. [CrossRef ]

7. Challet E, Gourmelen S, Pevet P, Oberling P, Pain L. Reciprocal relationships between general (propofol) anesthesia and circadian time in rats. Neuropsychopharmacology 2007;32(3):728-35. [CrossRef]

8. Debon R, Chassard D, Duflo F, Boselli E, Bryssine B, Allaouchiche $B$. Chronobiology of epidural ropivacaine variations in the duration of action related to the hour of administration. Anesthesiology 2002;96(3):542-45. [CrossRef ]

9. Simmons D. Lesker PA, Sherman N. Induction of sodium pentobarbital anesthesia. A circadian rhythm. J Interdiscip Cycle Res 1974;5(1):71-5.[CrossRef]

10. Koopmans R, Dingemanse J, Danhof M, Horsten GP, Boxtel $C J$. The influence of dosage time of midazolam on its pharmacokinetics and effects in humans. Clin Pharmacol Ther 1991;50(1):16-24. [CrossRef]

11. Munson ES, Martucci RW, Smith RE. Circadian variations in anesthetic requirement and toxicity in rats. Anesthesiology 1970;32(6):507-14. [CrossRef ]

12. Kerdelhue, B, Palkovits $M$, Karteszi M, Reinberg A. Circadian parathion in substance $\mathrm{P}$, luliberin $(\mathrm{LH}-\mathrm{RH})$ and thyroliberin (TRH) contents in hypothalamic and extrahypothalamic brain nuclei of adult male rats. Brain Res 1981;206:405-13.

13. Aya AG, Vialles N, Mangin R, Robert C, Ferrer JM, Ripart J, et al. Chronobiology of labour pain perception: an observational study. Br J Anaesth 2004;93(3):451-3. [CrossRef]

14. Morris RW, Lutsch EF. Susceptibility to morphine-induced analgesia in mice. Nature 1967;216(5114):494-5. [CrossRef ]

15. Liu X, Song J. Chronopharmacology of tramadol in mice. Yao Xue Xue Bao 2001;36(8):561-4.

16. Auvil-Novak SE, Novak R, Smolensky MH, Kavanagh JJ, Kwan JW, Wharton JT. Twenty-four hour variation in selfadministration of morphine sulfate and hydromorphone by post-surgical gynecologic cancer patients. Ann Rev 
Chronopharmacol 1988;5:343-6.

17. Boom M, Grefkens J, van Dorp E, Olofsen E, Lourenssen G, Aarts $L$, et al. Opioid chronopharmacology: Influence of timing of infusion on fentanyl's analgesic efficacy in healthy human volunteers. J Pain Res 2010;3:183-9. [CrossRef]

18. Anastasopoulou-Sampani D, Sampanis E, Karargiris G. The need for analgesia in elective cholecystectomies influenced by the time of day the operation is performed. Acta Anaesthesiol Scand 1996;40(8):955. [CrossRef]

19. Gupta SK, Southam MA, Hwang SS. Evaluation of diurnal variation in fentanyl clearance. J Clin Pharmacol 1995;35(2):159-62. [CrossRef]

20. Pan PH, Lee $S$, Harris L. Chronobiology of subarachnoid fentanyl for labor analgesia. Anesthesiology 2005;103(3):5959. [CrossRef]

21. Debon R, Boselli E, Guyot R, Allaouciche B, Lemmer B, Chassard D. Chronopharmacology of intrathecal sufentanil for labor analgesia daily variations in duration of action. Anesthesiology 2004;101(4):978-82. [CrossRef]

22. Halsas $M$, Hietala J, Veski $P$, Jürjenson $H$, Marvola M. Morning versus evening dosing of ibuprofen using conventional and time-controlled release formulations. Int J Pharm 1999;189(2):179-85. [CrossRef]

23. Cui Y, Sugimoto K, Araki N, Fujimura A. Evaluation of chronopharmacodynamics of indomethacin by the kaolin-induced pain model in mice. Chronobiol Int 2003;20(3):47384. [CrossRef]

24. Lemmer B, Wiemers R. Circadian changes in stimulus threshold and in the effect of a local anaesthetic drug in human teeth: studies with an electronic pulptester. Chronobiol Int 1989;6(2):157-62. [CrossRef ]

25. Njus D, Sulzman FM, Hastings J. Membrane model for the circadian clock. Nature 1974;248(5444):116-20. [CrossRef ]

26. Ede MC, Brennan MF, Ball MR. Circadian variation of intercompartmental potassium fluxes in man. J Appl Physiol 1975;38(1):163-70. [CrossRef ]
27. Chassard D, Duflo F, de Queiroz Siqueira M, Allaouciche B, Boselli E. Chronobiology and anaesthesia. Curr Opin Anaesthesiol 2007;20(3):186-90. [CrossRef ]

28. Meis PJ, Buster JE, Kundu N, Magyar D, Marshall JR, Halberg F. Individualized cosinor assessment of circadian hormonal variation in third trimester human pregnancy. Chronobiologia 1983;10(1):1-11.

29. Dickmeis T. Glucocorticoids and the circadian clock. J Endocrinol 2009;200(1):3-22. [CrossRef]

30. Kametani $\mathrm{H}$, Kawamura $\mathrm{H}$. Circadian rhythm of cortical acetylcholine release as measured by in vivo microdialysis in freely moving rats. Neurosci Let 1991;132(2):263-6.

31. Lindow SW, Newham A, Hendricks MS, Thompson JW, van der Spuy ZM. The 24-hour rhythm of oxytocin and betaendorphin secretion in human pregnancy. Clinical Endocrinol 1996;45(4):443-6. [CrossRef ]

32. Räisänen I. Plasma levels and diurnal variation of $\beta$-endorphin, $\beta$-lipotropin and corticotropin during pregnancy and early puerperium. Eur J Obstet Gynecol Reprod Biol 1988;27(1):13-20. [CrossRef ]

33. Fabbian F, Smolensky MH, Tiseo $R$, Pala $M$, Manfredini $\mathrm{R}$, Portaluppi F. Dipper and non-dipper blood pressure 24-hour patterns: Circadian rhythm-dependent physiologic and pathophysiologic mechanisms. Chronobiol Int 2013;30(1-2):17-30. [CrossRef]

34. Bruguerolle B, Labrecque G. Rhythmic pattern in pain and their chronotherapy. Adv Drug Deliv Rev 2007;59(910):883-95. [CrossRef ]

35. Desai S, Leong SB, Yvonne L, Sia A. Chronobiology of parturients receiving neuraxial labour analgesia with ropivacaine and fentanyl: A prospective cohort study. Int J Obstet Anesth 2009;18(1):43-7. [CrossRef ]

36. Milner AR, Bogod DG, Harwood RJ. Intrathecal administration of morphine for elective Caesarean section: $A$ comparison between $0.1 \mathrm{mg}$ and $0.2 \mathrm{mg}$. Anaesthesia 1996;51(9):871-3. [CrossRef ] 